\title{
The Rabbit in Australia
}

$\mathrm{T}^{\mathrm{o}}$ O-DAY every country is shy of introducing any mammal or bird which is not already a permanent resident, recognising that it may introduce a fresh element upsetting the balance of Nature of its land. Great Britain has had experience of the black and brown rats for centuries, perhaps accidental introductions; and has lately incurred liabilities, which may be enormous, by the purposeful introduction of the American musk-rat, already the major pest of Central Europe ; and the escape of the grey squirrel from the London Zoo. The rabbit also is held by Hinton to have been an introduction by the Normans; there are no mentions of warrens in Domesday Book. The English sparrow is only too well known in the United States and other countries. All pale into insignificance when compared with the rabbit in Australia, which, if control fails, will assuredly devastate a continent. The earliest arrivals, probably domesticated forms, were passengers on the first fleet of settlers 149 years ago. In Tasmania, rabbits were "running about some of the large estates in thousands" by 1827. Many of the smaller islands were also being stocked to provide food for shipwrecked mariners. On the mainland such areas where they flourished were hemmed in by forests, containing natural enemies, carnivorous mammals and birds. Then in 1859, two dozen wild rabbits were introduced to a Geelong estate, on which 20,000 were killed in the next six years, an estimated stock of 10,000 being left. To-day, three quarters of the continent is over-run.

The rabbit was originally an inhabitant of North Africa and southern Europe. The Romans carried it everywhere, sometimes (Majorca) with disastrous results. It is extraordinarily prolific, commencing to breed at four months of age and dropping up to six litters a year with an average of six young at each. The young can look after themselves when a fortnight old. If in any country there are suitable crevices in rocks or holes in the ground or protection by fallen timber, the young rabbit does not burrow, but in open country they dig holes, extending to 7-8 feet deep and often to great length; thus many living together form extensive warrens. The doe excavates a special burrow of its own, usually near the surface of the warren, where the earth is easiest to dig.

Essentially, the rabbit is an inhabitant of the plains, and at Geelong were the plains which form the greater part of Australia, with no enemies capable of keeping such a prolific animal in check. The inhabited parts were mostly laid out in sheep runs. Competition commenced, both rabbits and sheep eating the same food; the rabbit preferred the finer and more nutritious grasses and was a closer feeder and thus won in the struggle. So long as they were not too numerous, the stockmen liked them, for what did it matter if they were a few sheep less, while they had a variety in their food and especially a perquisite by the sale of rabbit skins. It was very shortsighted, for when drought came, the rabbit always won, for the sheep died first and more than sufficient rabbits were left. Then came wet seasons and the rabbit multiplied and pushed out into the semi-desert with its isolated bushes and low trees and its tussocks of grass. In turn drought came; the grass was eaten and the bush and the trees ringed and killed. What were merely 'dry lands' become desert with no plants to hold the drifting sand. Sheep cannot live on prickly pear, the only vegetation left, but rabbits can. In Australia the immediate problem is the productivity of wool and mutton reduced to about half in many pastoral districts; when the quantities of these are so reduced that the land no longer pays, it is gradually converted to desert.

The experiments in control at first made in Australia failed. The fox, who listens for the doe and her young and digs them out, was introduced, but the fox turns his attention to lambs and chickenand, of course, kills out much of the native fauna. The efforts of Governments were mainly to prevent the spread of rabbits; thus Queensland tried to protect itself by no less than 6,303 miles of wire fencing. Ring fences were erected in places and often separate stations within these were again ringed. Western Australia ran a fence 1,139 miles without a break, and as part of this seemed ineffective two subsequent inner fences of 724 miles and 160 miles. Trapping and digging are too expensive-and poisons, while undoubtedly effective at times, never clear the whole stock; and they kill everything harmful and beneficial, fur and feather. Carbon disulphide was used as a fumigant, but even in a burrow its effect is very brief and many rabbits escaped; the same applies to carbon monoxide. Then the natural diseases of rabbits were studied and a virus was tried, but there was always left a resistant stock with which to carry on.

Mr. D. G. Stead, as Rabbit Enquiry Commissioner to the State of New South Wales, now 
advocates the use of 'Cyanogas'*, and this to us seems the soundest proposal as yet formulated. Cyanogas is calcium cyanide in dust form, and this in contact with ground moisture or water vapour gives off hydrocyanic acid gas, which is the most deadly fumigant known. It is quite safe to handle in the portable foot machine, and the method is to blow a few puffs into the mouth of a warren, their number depending on its size, and then to close up and stamp down every hole with the spade, and leave the warren, into which dogs had previously driven all wanderers. The Cyanogas takes up to a day to decompose and is all this time giving off its gas, which diffuses so well that it penetrates to every part of the burrow.

Mr. Stead's figures are convincing, and his claim that this fumigant gives "the greatest kill possible" and entails "the least possible use of time and energy" seems justifiable; certainly at the esti-

- The Rabbit in Australia : History, Life Story, Habits, Effect upon Australian Primary Production and Best Means of Extermination. By David G. Stead. Pp. 108. (Watson's Bay, N.S.W.: The Anthor; London: University of London Animal Welfare Society, 1935.) 28 net. mated cost of $6 d$. per acre (or even at four times as much !) its use means "the lowest cost". In Australia it is claimed that the better sheep lands could be thus safeguarded, and their extra productiveness in wool and flesh would mean a handsome profit on the deal. Is it not also equally applicable to England, where rabbits have been selling everywhere in the country at $6 d$. a piece or less in the past winter? The shooting of rabbits is poor sport, and the eaten-off crops that surround many fields mean often a loss of 10 per cent of the crop of a farm, and must be abolished, if farming is to pay. No doubt the Ministry of Agriculture is alive to the use of Cyanogas, but in our experience few farmers or land owners know of it, and those who do mostly regard its use as highly dangerous. It is a fumigant applicable to the brown rat and perhaps the musk-rat, but in each case it requires to be used according to the mode of life of the beast. In any event, there is some hope now that these rodent pests may be controlled.
J. S. G.

\section{Obituary}

\section{Prof. James Rice}

JAMES RICE, who died on April 17 at the age $\mathcal{J}$ of sixty-two years, was associate-professor of physics and reader in theoretical physics in the University of Liverpool. He was educated at the Royal Academical Institution, and the Queen's College, Belfast (now the Queen's University, Belfast), where he obtained the highest honours (Senior Scholarship and Dunville Studentship). In the Royal University of Ireland his career was equally distinguished (scholar, student and junior fellow), and at the examinations for the B.A. and M.A. degrees and the junior fellowship he was awarded the highest place in the first-class honours list in mathematical science. In 1902 he was appointed senior physics master at the Liverpool Institute, a post which he held until 1914, when he was appointed to a senior lectureship in physics in the University of Liverpool. In 1924 the University of Liverpool conferred on him the title and status of associate-professor, and in 1935 the additional title and status of reader in theoretical physies.

In the earlier part of his career, Rice was particularly attracted to those branches of mathematical physics which deal with thermodynamics, kinetic theory and classical statistical mechanics, and soon obtained a mastery of all these subjects. Being gifted with a keenly receptive and flexible mind as well as an outstanding ability in mathematical science, he soon became an enthusiastic and expert student of the new advances in theoretical physicsPlanck's theory of the quantum of action, the
Robb-Einstein-Minkowski theory of relativity, the Rutherford-Bohr theory of the atom, and the later advances in the quantum mechanical theory of atomic and molecular events due to Heisenberg, Born, Schrödinger, Bohr, Dirac and Weyl.

Rice's early mastery of the general theory of relativity was demonstrated in the clearest fashion by the publication in 1923 of his "Relativity; a Systematic Treatment of Einstein's Theory" (Longmans, Green and Co., Ltd.). Although not intended to compete with the great treatise of Eddington (from whom Rice's work received a highly favourable notice in the columns of this journal), this book dealt in a thoroughgoing fashion with the complete mathematical theory of the subject, and soon became the best text-book in the English language for serious university students of theoretical physics.

Being convinced of the fundamental importance of the new outlook on science and philosophy due to the concepts of the modern theory of relativity, Rice became a devoted advocate of these views and gave highly appreciated 'popular' lectures thereon in many parts of the country, being invited by the Parliamentary Science Group to expound the new ideas to the members. His book on relativity in Benn's well. known sixpenny series had an immense sale, and probably did more than any other work on the subject to spread the new concepts among the thinking and more intelligent sections of the British public. Throughout his whole life, Rice was an enthusiastic and expert apostle of the new and wonderful light that had come into the minds of 